\title{
Breast Cancer pT4c TNM Finding v6 and v7
}

National Cancer Institute

\section{Source}

National Cancer Institute. Breast Cancer pT 4C TNM Finding v6 and v7. NCI Thesaurus. Code C48988.

Breast cancer with extension to the chest wall, not including the pectoralis muscle, and with edema (including peau d'orange) or ulceration of the skin of the breast or satellite skin nodules confined to the same breast. (from AJCC 6th and 7th Eds.) 